\title{
Epiphytic lichens of the dark coniferous forest within the outbreak of Ips sexdentatus Boern. in the Maly Abakan site of the Khakassky Nature Reserve
}

\author{
Evgenia Makeeva ${ }^{1,2^{*}}$, Olga Zyryanova ${ }^{1}$ \\ ${ }^{1}$ Khakas State University named after N.F. Katanov, 90 Lenin St., 655000 Abakan, Russia \\ ${ }^{2}$ State Nature Reserve «Khakasskii», 164 Tsukanova St., Abakan, Russia
}

\begin{abstract}
The article demonstrates the results of studies epiphytic lichens species composition from the territory of the Khakassky State Nature Reserve, conducted in the alpine cedar taiga at the location of the Ips sexdentatus outbreak. There were two types of sample plots: damaged plots, characterized by shriveled cedars infected by bark beetle and flawless plots containing forest stand of primarily vigorous trees. All sample plots were found to comprise 46 species of lichens belonging to 24 genera and 13 families. It was observed that plots infected by bark beetle were inhabited by lichens with poor vital activities manifested by their damaged thalli. However, there were no evident changes in the epiphytic lichen communities on floristic and coenotic levels.
\end{abstract}

\section{Introduction}

Epiphytic lichens are one of the components of the boreal forest communities. The characteristics of the epiphytic lichen cover are closely related to certain environmental factors and naturally change in accordance with the changes in environmental conditions. One of such factors, for instance, may be density and length of tree crowns which serve as samples for descriptions [1].

The Maly Abakan site is one of the cluster sites of the Khakassky State Nature Reserve, located in the mid-mountain and high-mountain parts of the Western Sayan northern macroslope. The mountain-taiga belt occupies $80 \%$ of the site territory. The most part of the site is represented by taiga dark coniferous forests composed of cedars and firs primarily forming the mixed stands [2].

In recent decades the Maly Abakan site has been found to comprise the shriveling Siberian cedar tree stands exposed to Ips sexdentatus Boern. Besides, the state of cedar forests has been monitored $[3,4]$. The years of the maximum distribution of bark beetles on the site are 2000 and 2010. Therefore, the aim of this study is to identify species composition of the epiphytic lichen cover at the location of the Ips sexdentatus outbreak on the Maly Abakan site of the Khakassky Nature Reserve.

\footnotetext{
*Corresponding author: meg77@yandex.ru
} 


\section{Material and methods}

The species composition of epiphytic lichens was studied at four permanent sample plots (20x20 m in size) located in two study areas. The first plot - Nizhny is located in the vicinity of Nizhny cordon. This plot included sample plots Nd (Nizhny damaged) and Nf (Nizhny flawless). The plots are located on the second terrace of the Maly Abakan River at altitude of $730 \mathrm{~m}$ above sea level. The plots are characterized with cedar-fir and moss-forb forests. The coordinates of the sample plot $\mathrm{Nd}$ are $52^{\circ} 11^{\prime} 07.4^{\prime \prime} \mathrm{N} ; 089^{\circ} 03^{\prime} 36.6^{\prime \prime} \mathrm{E}$. According to observations there was an active damage in the cedar stand with absence of vigorous trees, while the old-dried trees accounted for $72 \%$. The coordinates of the sample plot of Nf are $52^{\circ} 11^{\prime} 09.4^{\prime \prime} \mathrm{N} ; 089^{\circ} 03^{\prime} 41.4^{\prime \prime}$ E. The forest stand of the plot was comprised of $80.2 \%$ of the totally vigorous and slightly weakened cedar trees [5].

The second plot (Otkyl) is located in the mouth of the Otkyl River. There were sample plots Od (Otkyl damaged) and Of (Otkyl flawless) located at altitude of $790 \mathrm{~m}$ above sea level. The plot is characterized by cedar-fir and gramineous-forb forests. The sample plot Od is located on the first terrace of the Maly Abakan River with the following coordinates $52^{\circ} 07^{\prime} 21.2^{\prime \prime} \mathrm{N} ; 089^{\circ} 04^{\prime} 08.8^{\prime \prime}$ E. The plot was comprised of $79 \%$ of the old dead wood in the total composition of the forest stand. The sample plot Of is located on mountain slope with following coordinates: $52^{\circ} 08^{\prime} 04.2^{\prime \prime} \mathrm{N} ; 089^{\circ} 04^{\prime} 35.5^{\prime \prime}$ E. The forest stand of the plot was composed of $90 \%$ of the vigorous and slightly weakened trees. 10 phorophytic trees Pinus sibirica Du Tour (5), Abies sibirica Ledeb. (5) from each plot were selected for studies. The lichens were collected from the trunks at four heights: 0.6, 0.9, 1.2 and $1.5 \mathrm{~m} \mathrm{[6].}$

\section{Results and discussion}

Two studied sites were found to comprise 46 species of lichens belonging to 24 genera and 13 families. An average value of species in the family is $3.5 \%$; while the following families identified as dominant in the studied flora have the values exceeding this indicator: Parmeliaceae Zenker (24 species, 52.8\%) and Cladoniaceae Zenker (6 species, $13.2 \%$ ). The single-species families are Alectoriaceae (Hue) Tomas, Coniocybaceae Reichenb, Lecanoraceae Körb., Lobariaceae Chevall., Mycoblastaceae Hafellner, Bacidiaceae W. Watson, Mycobilimbiaceae Hafellner.

An average value of species in genus is $1.92 \%$. The dominant lichen genera in studied area are Cladonia Hill. ex P. Browne (6 species, $13.2 \%$ ), Bryoria Brodo et D. Hawksw. (6 species, $13.2 \%$ ), Usnea Dill. ex Adans. (4 species, $8.8 \%$ ), Hypogymnia (Nyl.) Nyl. (3 species, $6.6 \%$ ).

Based on the classification by N. V. Sedelnikova [7], in terms of relation to humidity, snow cover thickness and temperature factor there are 2 ecological groups among the studied epiphytic lichens. They are mesophytes (45 species, $97.8 \%$ ) and xeromesophytes (1 species, $2.2 \%$ ). This ratio of dominant families, genera, and ecological groups reflects peculiarities of the boreal floras of the Holarctic $[8,9]$.

Geographical analysis of epiphytic lichens in studied sites demonstrated predominance of the boreal geographical element (22 species, $48.4 \%$ ) together with nemoral (8 species, $17.6 \%$ ) and mountain (6 species, $13.2 \%$ ) elements. Analyzing the type of habitat one can say that the holarctic (17 species, $37.4 \%$ ) and pluriregional (13 species, $28.6 \%)$ lichens are predominant.

Consider the species composition of lichens on different sites and sample plots. The total number of lichens found on the damaged and flawless plots nearby the Nizhny cordon is 39 species, whilst the lichens found in the mouth of the Otkyl River account for 23 species. The Jaccard similarity coefficient $\left(\mathrm{K}_{\mathrm{J}}\right)$ for the two studied sites is 0.35 , which indicates rather weak similarity of the species composition. 
Common species for the two studied plots were Chaenotheca ferruginea (Turner ex Sm.) Mig., Hypogymnia physodes (L.) Nyl., H. vittata (Ach.) Parrique, Lecanora carpinea (L.) Vain., Lobaria pulmonaria (L.) Hoffm., Nephromopsis laureri (Kremp.) Kurok., Parmelia sulcata Taylor, Pertusaria amara (Ach.) Nyl., Physcia adsendens (Fr.) H. Olivier, Platismatia glauca (L.) W. L. Culb. et C. F. Culb., Ramalina dilacerata (Hoffm.) Hoffm., Tuckemanopsis chlorophylla (Willd.) Hale, Usnea dasopoga (Ach.) Nyl., U. glabrescens (Nyl. ex Vain.) Vain., U. longissima Ach., Vulpicida pinastri (Scop.) J.E. Mattsson et M. J. Lai.

Specific species for the plot in the mouth of the Otkyl River included Bryoria simplicior (Vain.) Brodo et D. Hawksw., Cladonia bacilliformis (Nyl.) Glück, Cl. gracilis (L.) Willd., Cl. rei Schaer., Cl. squamosa Hoffm., Lecidea turgidula Fr., Ramalina pollinaria (Westr.) Ach.

Specific species for the plot located in the vicinity of the Nizhny cordon consisted of Alectoria sarmentosa (Ach.) Ach., Bacidia circumspecta (Nyl. ex Vain.) Malme, Bryoria capillaris (Ach.) Brodo et D. Hawksw, B. furcellata (Fr.) Brodo et D. Hawksw., B. fuscescens (Gyeln.) Brodo et D. Hawksw., B. implexa (Hoffm.) Brodo et D. Hawksw., B. nadvornikiana (Gyeln.) Brodo et D. Hawksw., B. tortuosa (G. Merr.) Brodo et D. Hawksw., Cetrelia cetrarioides (Delise et Duby) W. L. Culb. et C. F. Culb., Cladonia coniocraea (Flörke) Spreng., Cl. fimbriata (L.) Fr, Evernia mesomorpha Nyl., E. esorediosa (Müll. Arg.) Du Rietz, Hypogymnia bitteri (Lynge) Ahti, Lecania cyrtella (Ach.) Th. Fr., Lecidea albofuscescens Nyl., Melanelia exasperata (De Not.) Essl., Mycobilimbia hypnorum (Lib.) Kalb et Hafellner, Mycoblastus affinis (Schaer.) T. Schauer, Parmelia squarrosa Hale, Pertusaria flavida (DC.) J. R. Laundon, Physcia tenella (Scop.) DC., Usnea hirta (L.) Weber ex F. H. Wigg.

The damaged and flawless sample plots of the studied sites had the similar number of species. The number of lichens species found on the plots can be described as follows: $\mathrm{N}_{\mathrm{d}}$ plot -25 species, $\mathrm{N}_{\mathrm{f}}-28$ species, $\mathrm{O}_{\mathrm{d}}$ and $\mathrm{O}_{\mathrm{f}}-15$ species each.

Pinus sibirica of the Nizhny site was found to comprise 18 species of lichens on each of $\mathrm{N}_{\mathrm{d}}$ and $\mathrm{N}_{\mathrm{f}}$ plots; 11 species on the $\mathrm{O}_{\mathrm{d}}$ plot and 13 species on the $\mathrm{O}_{\mathrm{f}}$ plot. Consequently, the number of lichen species on the sample plots is essentially independent of the degree of damages observed in Pinus bark.

Epiphytic species on Pinus sibirica found only on the flawless plot $\mathrm{N}_{\mathrm{f}}$ include Bacidia circumspecta, Cetrelia cetrarioides, Hypogymnia bitteri, Lecania cyrtella, Mycobilimbia hypnorum, Mycoblastus affinis, Parmelia squarrosa, Platismatia glauca, Ramalina dilacerata; on the flawless plot $\mathrm{O}_{\mathrm{f}}$ : Bryoria simplicior, Cladonia gracilis, Hypogymnia physodes, Lecidea turgidula, Lobaria pulmonaria, Platismatia glauca, Ramalina dilacerata, Tuckermanopsis chlorophylla.

The plots infected by bark beetle were found to have some species which were absent on the flawless plots. These species included Bryoria implexa, B. nadvornikiana, Chaenotheca ferruginea, Evernia esorediosa, Melanelia exasperata, Pertusaria flavida, Physcia adscendens, P. tenella, Vulpicida pinastri located on Pinus sibirica of the plot $\mathrm{N}_{\mathrm{d}}$; and Cladonia rei, Nephromopsis laureri, Parmelia sulcata, Pertusaria amara, Physcia adscendens, Usnea longissima located on the plot $\mathrm{O}_{\mathrm{d}}$.

In contrast to Pinus sibirica, Abies sibirica is a forophyte with a smooth and undamaged bark. Species compositions of epiphytic lichens on Abies can only be influenced by the changes in light environment in biotopes with shrivelling Pinus. Abies sibirica was found to have 27 species of lichens in the Nizhny site and 17 species in the Otkyl site. 17 species of lichens were found on the plot $\mathrm{N}_{\mathrm{p}}$ and 20 species on the plot $\mathrm{N}_{\mathrm{f}}$, of the Nizhny site, while the Otkyl site comprised 9 species on the plot $\mathrm{O}_{\mathrm{d}}$ and 10 species on the plot $\mathrm{O}_{\mathrm{f}}$. The total number of species found on Pinus (on the area of all plots) was 34, on Abies - 32. 
When comparing lichen biota of all the plots affected by the bark beetle and the flawless plots, only a few species were found to be reducing in number on the damaged biotopes. They were Platismatia glauca (reducing from $25.0 \%$ on the flawless plots to $10.0 \%$ on the damaged plots), Hypogymnia physodes (from $22.5 \%$ to $10.0 \%$ ), Vulpicida pinastri (from $17.5 \%$ to $5.0 \%$ ).

In case when trees are damaged by bark beetles, the properties of the vegetation substrate are also changed which can directly affect the expansion of lichens. The studied plots demonstrated changes in the morphology of thalli in lichens living on the trees damaged by bark beetles. The necrosis of blastema was mostly observed in foliose (Lobaria pulmonaria, Parmelia sulcata, Cetrelia cetrarioides) and fruticose (Cladonia coniocraea, Cladonia fimbriata) epiphytic lichens. Moreover, their colour, number of reproductive structures and soredial properties of thalli had undergone certain changes.

\section{Conclusion}

Two selected sites initially differed from each other in species composition, the largest number of species was found on the Nizhny site. The number of lichen species in the areas affected by the bark beetle does not serve as marker of inhibition of epiphytic communities, as the damaged and intact sample plots are quite comparable in terms of the species number. Besides, the part of the species was found only on the flawless plots, as well as the other part was characteristic only for the damaged plots. In our case, it is the damage of the thalli that indicates the inhibition of the vital activity of lichens in the areas affected by the bark beetle, even in the absence of changes in the epiphytic lichen communities at the floristic and coenotic levels.

This work was supported by the RFFI grant 18-44-190004 r_a Assessment of the state of pine forests of the Republic of Khakassia in the place of localization of breeding outbreak of reproduction of secondary stem pest Ips sexdentatus (on the example of the Maly Abakan natural boundary, Khakassky Reserve).

\section{References}

1. Methods of studying of forest communities (NIIHimiya SPbSU, St. Petersburg, 2002)

2. Khakassky Reserve: a scientific publication (Journalist, Abakan, 2001)

3. I.L. Maymanakova, Scientific research of reserves and national parks of Southern Siberia, 1 (2011)

4. I.L. Maymanakova, Scientific research of reserves and national parks of Southern Siberia, 4 (2014)

5. I.L. Isaeva, Achievements of modern natural sciences, 12 (1) (2018)

6. A.V. Pchelkin, V.B. Slepov, The use of algae and lichens in environmental monitoring and bioindication studies (MGSUN, Moscow, 2004)

7. N.V. Sedelnikova, Lichens of Altai and Kuznetsk highlands: Summary of flora (Science, Novosibirsk, 1990)

8. N.S. Golubkova, Analysis of lichen flora of Mongolia (L., Science, 1983)

9. O.A. Zyryanova, In the world of discoveries. Series: Natural and technical science, 12.1 (60) (2014) 